\title{
Synthesis, Characterization, Antibacterial and DNA Binding Studies of Mn (II) Complex of 3-(2-(2-Hydroxy-3- Methoxybenzylidene) Hydrazinyl) Quinoxalin-(1H)-One
}

\author{
P.Sukanya ${ }^{1}$ and Ch.Venkata Ramana Reddy ${ }^{2 *}$ \\ ${ }^{I}$ Department of Chemistry, Vasavi College of Engineering, Hyderabad, Telangana -500031, India \\ ${ }^{2}$ Department of Chemistry, Jawaharlal Nehru Technological University Hyderabad, Hyderabad, Telangana \\ India
}

\begin{abstract}
M n$ (II) complex of the Schiff base (L), 3-(2-(2-hydroxy-3-methoxybenzylidene) hydrazinyl) quinoxalin-2(1H)-one (VHQO) was prepared and characterized by IR, UV-VIS, Mass, Elemental analysis, TGDTA, magnetic susceptibility and conductivity measurements. VHQO behaved as monobasic, tridentate ligand and formed 1:2 complex $\left(M L_{2}\right)$ with the metal ion $(M)$ coordinating through ring nitrogen, azomethine nitrogen and phenolic oxygen. Thermal analysis of the complex indicated the absence of lattice and coordinated water. Based on the spectral and analytical data, octahedral geometry was assigned to the complex. Antibacterial activity of the complex against gram positive bacteria, Bacillus subtillis, Staphylococcus aureus, and gram negative bacteria, Escherichia coli, Proteus vulgaris, Pseudomonas aeroginosa, and Klebsiella pneumonia was studied. The interaction of the complex with Calf Thymus DNA (CT-DNA) was studied by absorption spectroscopy and the intrinsic binding constant was calculated.
\end{abstract}

Keywords: Schiff base, tridentate ligand, Metal complex, DNA binding, Anti bacterial.

\section{Introduction}

Transition metal complexes of Schiff base ligands are known for their potential applications in antibacterial, antifungal, magnetic, photoluminescent and DNA binding properties [1-11]. During recent years, quinoxaline based Schiff bases emerged as an important class of ligands and formed metal complexes with a broad spectrum of biological activity [12-17].Owing to the significant chemical, catalytic and biological activities of the Schiff base complexes, the present communication reports the synthesis, characterization and biological activity of Mn (II) complex of the Schiff base ligand, 3-(2-(2-hydroxy-3-methoxybenzylidene) hydrazinyl) quinoxalin-2(1H)-one (VHQO).

\subsection{Materials and methods}

\section{Experimental}

All chemicals used were of reagent grade and were used without any prior purification. O-phynelenediamine was purchased from Loba Chemie India. Oxalic acid, hydrazine hydrate, o-vanillin and metal chloride were purchased from Merck. Calf-thymus DNA was purchased from Sigma. IR spectra were recorded in $\mathrm{KBr}$ pellets from 250 to $4000 \mathrm{~cm}^{-1}$ using SCHIMADZU FTIR-5300 spectrometer. Electronic spectra were recorded on Shimadzu UV-3600 spectrometer. ${ }^{1} \mathrm{H}$ NMR spectrum was recorded in DMSO $\mathrm{d}_{6}$ solvent with Bruker $400 \mathrm{MHz}$ spectrometer. Thermo gravimetric analysis was carried using TG/DTA EXTAR 6300 in the temperature range of $25^{\circ} \mathrm{C}$ to $800^{\circ} \mathrm{C}$ with a heating rate of $10^{\circ} \mathrm{C} / \mathrm{min}$ under Nitrogen atmosphere. Elemental analysis was carried out using FLASH Ea 1112 SERIES CHNS analyzer. Electrical conductance measurements were recorded using $10^{-3} \mathrm{M}$ solutions of the complexes in DMSO with an Elico conductivity bridge and dip type cell calibrated with $\mathrm{KCl}$ solution. Magnetic susceptibilities were measured on a Faraday balance model 7550 at room temperature using $\mathrm{Hg}\left[\mathrm{Co}(\mathrm{NCS})_{4}\right]$ as calibrant. Diamagnetic corrections were computed using Pascal's constants.

2.2. Synthesis of 3-(2-(2-hydroxy-3-methoxybenzylidene) hydrazinyl) quinoxalin-2(1H)-one (VHQO)

Synthesis of 3-(2-(2-hydroxy-3-methoxybenzylidene) hydrazinyl) quinoxalin-2(1H)-one (VHQO) (L) involves 3 steps

2.2.1. Synthesis of quinoxaline-2,3(1H,4H)-dione

O-phenylene diamine $(100 \mathrm{~m} . \mathrm{mol})$ and oxalic acid $(100 \mathrm{~m} . \mathrm{mol})$ were dissolved in $50 \mathrm{ml}$ of $4 \mathrm{~N} \mathrm{HCl}$ and heated on water bath for 20 minutes. A crystalline solid was formed. The reaction mixture was cooled and the product was filtered, washed with water to remove traces of $\mathrm{HCl}$ and dried [18].

2.2.2. Synthesis of 3-hydrazinylquinoxalin-2(1H)-one 
Synthesis, Characterisation, Antibacterial and DNA binding studies of Mn (II) complex of 3-(2-(2-

A mixture of quinoxaline-2, $3(1 \mathrm{H}, 4 \mathrm{H})$-dione $(100 \mathrm{~m} . \mathrm{mol})$, hydrazine hydrate $(50 \mathrm{ml})$ and water $(50 \mathrm{ml})$ was heated under reflux for 2 hours. The reaction mixture was cooled and the yellow solid obtained was collected by filtration, washed with water and recrystallized from n-butanol [19]. Yield: 86\%

\subsubsection{Synthesis of 3-(2-(2-hydroxy-3-methoxybenzylidene) hydrazinyl) quinoxalin-2(1H)-one}

The Schiff base was prepared by the condensation of 3-hydrazinylquinoxalin-2(1H)-one with 2-hydroxy-3-methoxybenzaldehyde. 0.05 moles of 2-hydroxy-3-methoxybenzaldehyde in methanol was added drop wise to 0.05 moles of 3-hydrazino quinoxaline-2-one in methanol, a catalytic amount of acetic acid was added and the reaction mixture was stirred at room temperature for 30 minutes. The reaction was monitored by TLC using chloroform and methanol (9:1). The yellow solid obtained was collected by filtration, washed with methanol and n-hexane and dried over anhydrous calcium chloride. Yield 89\%, M.P. $224^{\circ} \mathrm{C}$.

\subsubsection{Synthesis of Mn (II) complex of VHQO}

Mn (II) complex is prepared by adding $100 \mathrm{~m} . \mathrm{mol}$ of hot methanolic suspension of VHQO in small increments to $50 \mathrm{~m} . \mathrm{mol}$ of a hot methanolic solution of $\mathrm{Mn}$ (II) chloride in a two necked round bottom flask. The $\mathrm{pH}$ of the reaction mixture was adjusted to $\approx 8$ using alcoholic ammonia. The reaction mixture was refluxed on a water bath for about three hours. The colored solid obtained was filtered in hot condition, washed successively with methanol and n-hexane and dried over anhydrous calcium chloride in a desiccator at room temperature.

\subsection{DNA binding studies}

CT-DNA solution was prepared in $\mathrm{KH}_{2} \mathrm{PO}_{4}$ and $\mathrm{K}_{2} \mathrm{HPO}_{4}$ buffer .The concentration of DNA was determined from the absorption intensity at $260 \mathrm{~nm}$ and $\varepsilon$ value $\left(6600 \mathrm{M}^{-1} \mathrm{~cm}^{-1}\right)$ [20, 21]. Electronic absorption titrations were performed by adding increased amounts of CT-DNA to the solution of the metal complex in DMSO. The solution after each addition of DNA was incubated for 10 minutes before recording of the absorption spectra. The intrinsic binding constant $\left(\mathrm{K}_{\mathrm{b}}\right)$ was determined using the following equation [22].

$$
\text { [DNA }] /\left(\varepsilon_{\mathrm{a}}-\varepsilon_{\mathrm{f}}\right)=[\mathrm{DNA}] /\left(\varepsilon_{\mathrm{b}}-\varepsilon_{\mathrm{f}}\right)+1 / \mathrm{K}_{\mathrm{b}}\left(\varepsilon_{\mathrm{b}}-\varepsilon_{\mathrm{f}}\right)
$$

Where, [DNA] represents the concentration of DNA in base pairs, $\varepsilon_{\mathrm{a}, \varepsilon_{\mathrm{b}}}$ and $\varepsilon_{\mathrm{f}}$ are apparent extinction coefficient, extinction coefficient for free metal complex and extinction coefficient for the metal complex in fully bound form respectively.

\subsection{Antibacterial studies}

The antibacterial activity of the complex was tested against Gram positive bacteria Staphylococcus aureus, Bacillus subtillis and Gram negative bacteria Escherichia coli, Proteus vulgaris, Pseudomonas aeroginosa, and Klebsiella pneumonia in the nutrient agar media by using DMSO as negative control.

\section{Results And Discussion}

The Mn (II) complex is stable in air, non hygroscopic, insoluble in water and common organic solvents but soluble in DMF and DMSO. The elemental analysis Calc. for $\mathrm{C}_{32} \mathrm{H}_{26} \mathrm{MnN}_{8} \mathrm{O}_{6}: \mathrm{C} 57.06 \%, \quad \mathrm{H} 3.89 \%$, and $\mathrm{N}$ 16.63\%; Found: C 56.92\%, H 3.76\%, and N 16.54\%. The ESI-MS: The molecular ion peak is observed at $\mathrm{m} / \mathrm{Z}=673.0084$. The mass and elemental analysis data are in good agreement with the formation of 1:2complex $\left(\mathrm{ML}_{2}\right)$. Magnetic moment value of the complex is calculated as 5.83 BM. The Molar Conductance value $\left(4.4 \Omega^{-1} \mathrm{Cm}^{2} \mathrm{~mol}^{-1}\right)$ indicates that the complex is non-electrolyte.

\subsection{IR Spectra}

IR spectrum of VHQO exhibited the characteristic bands at $3581 \mathrm{~cm}^{-1}$ v (OH) phenolic, $1678 \mathrm{~cm}^{-1}$ $v(\mathrm{C}=\mathrm{O}), 1614 \mathrm{~cm}^{-1} v(\mathrm{C}=\mathrm{N})$ free, $1465 \mathrm{~cm}^{-1} v(\mathrm{C}=\mathrm{N})$ ring and $1344 \mathrm{~cm}^{-1} v(\mathrm{C}-\mathrm{O})$. The band observed at $3581 \mathrm{~cm}^{-1}$ in the ligand due to $v(\mathrm{OH})$ stretching frequency is absent in the complex indicating the coordination of $-\mathrm{OH}$ group through deprotonation. Participation of phenolic group in coordination is further supported by the positive shift of $v(\mathrm{C}-\mathrm{O})$ peak at $1344 \mathrm{~cm}^{-1}$ of VHQO to $1357 \mathrm{~cm}^{-1}$ in the complex [2]. The characteristic azomethine $v(-\mathrm{CH}=\mathrm{N}-)$ peak observed at $1614 \mathrm{~cm}^{-1}$ in the IR spectrum of the VHQO appears at $1600 \mathrm{~cm}^{-1}$ in the complex suggesting the involvement of azomethine nitrogen in coordination [23]. Participation of ring nitrogen in coordination is evidenced by the negative shift of the $v(C=N)$ ring peak at $1465 \mathrm{~cm}^{-1}$ of the ligand to $1440 \mathrm{~cm}^{-1}$ in the complex. The peaks at 449 and $395 \mathrm{~cm}^{-1}$ in the complex are assigned to $v(\mathrm{Mn}-\mathrm{O})$ and $v(\mathrm{Mn}-\mathrm{N})$ respectively.

\subsection{Electronic Spectra}

Electronic absorption spectra of the ligand and the complex [Fig.1] recorded in DMSO showed peaks at 266 and $276 \mathrm{~nm}$ corresponding to $\pi-\pi *$ transitions and at 358,377 and $397 \mathrm{~nm}$ corresponding to $\mathrm{n}-\pi^{*}$ transitions. An absorption band at $457 \mathrm{~nm}$ in the electronic spectrum of $\mathrm{Mn}$ (II) complex assigned to ${ }^{6} \mathrm{~A}_{1 \mathrm{~g}} \rightarrow{ }^{4} \mathrm{~A}_{1 \mathrm{~g}}$ transition supports an octahedral geometry for the complex[24]. 


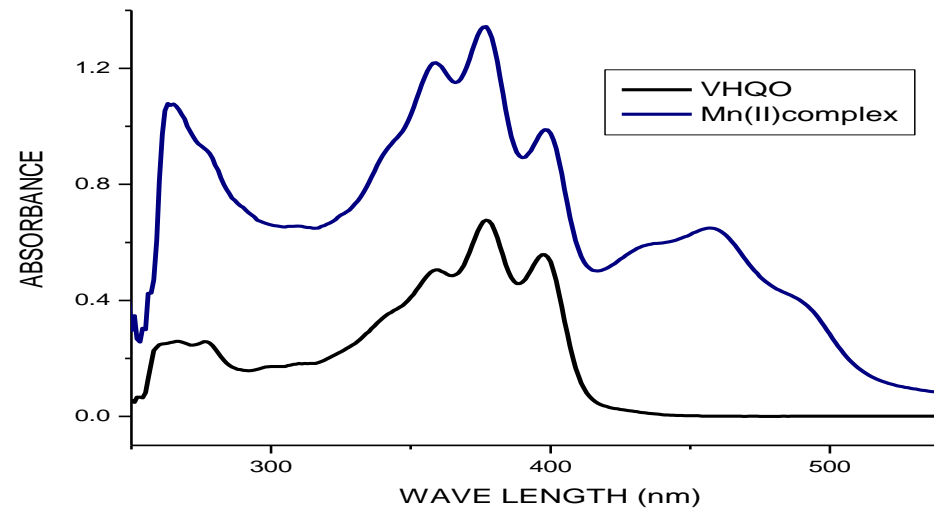

Fig.1. Electronic absorption spectra

\subsection{TGA-DTA}

Thermo gravimetric analysis (TGA) and Differential Thermal analysis (DTA) of the $\mathrm{Mn}$ (II) complex [Fig.2] indicate no appreciable weight loss up to $300^{\circ} \mathrm{C}$ and no endotherm and hence absence of lattice water as well as coordinated water. The complex decomposes in two stages between $300^{\circ} \mathrm{C}$ and $400^{\circ} \mathrm{C}$ as indicated by the exotherms.

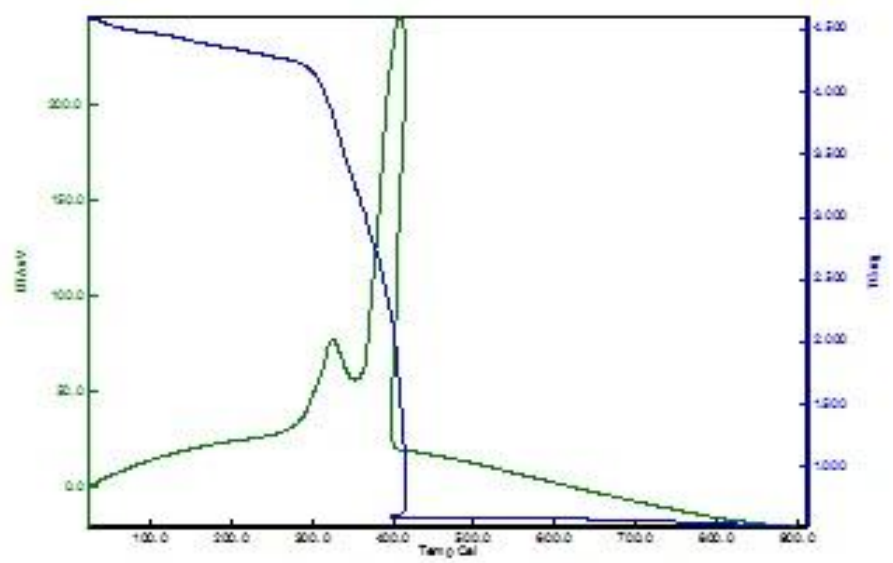

Fig .2.TG-DTA of Mn(II) Complex

Based on the spectral and analytical data, the proposed structure of the complex is shown in Fig.3

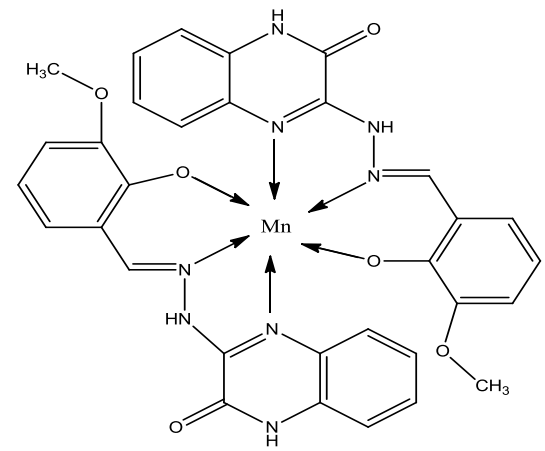

Fig.3. Proposed structure of Mn (II) complex of VHQO

\subsection{DNA binding studies}

The mode of binding of CT- DNA with Mn (II) complex was evaluated by electronic absorption titrations using the solution of the Mn (II) complex in DMSO [Fig.4]. The $\mathrm{K}_{\mathrm{b}}$ values were determined by the ratio of the slope to the intercept in the plots of [DNA]/ $\left(\varepsilon_{\mathrm{a}}-\varepsilon_{\mathrm{f}}\right)$ vs [DNA]. Significant hypochromism was noticed on increasing concentration of CT-DNA, indicating intercalation mode of binding of the complex with DNA [25]. The $\mathrm{K}_{\mathrm{b}}$ value $4.416 \times 10^{6}\left(\mathrm{M}^{-1}\right)$ indicate the strong affinity of the complex to bind with DNA. 


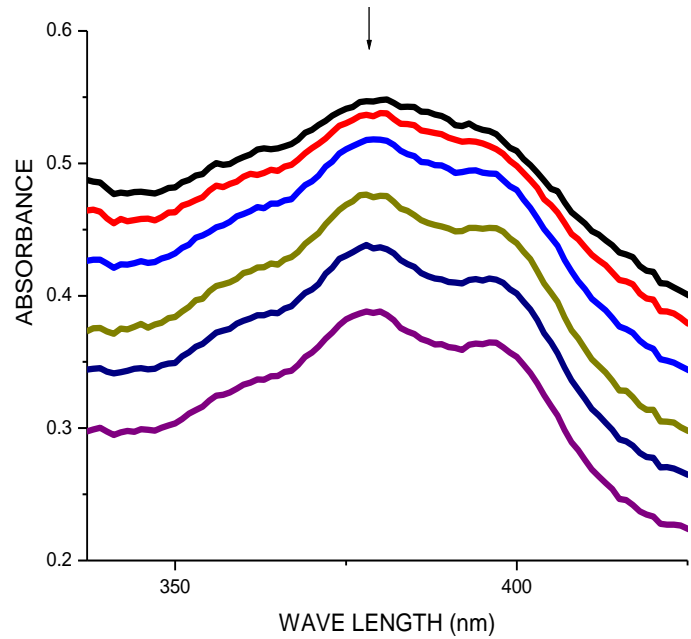

Fig.4. The absorption spectra of Co (II) complex in the presence and absence of CT DNA

\subsection{Antibacterial studies}

The antibacterial study of the metal complex showed moderate activity against Staphylococcus aureus and Bacillus subtillis with a zone of inhibition of $11 \mathrm{~mm}$, and $12 \mathrm{~mm}$ respectively. However, the activity against the other bacterial strains Escherichia coli, Proteus vulgaris, Pseudomonas aeroginosa, and Klebsiella pneumonia was found to be less significant.

\section{Conclusions}

Mn (II) complex of the tridentate Schiff base ligand (L), 3-(2-(2-hydroxy-3-methoxybenzylidene) hydrazinyl) quinoxalin-2(1H)-one was prepared and characterized by various spectral and analytical techniques. The ligand behaved as $\mathrm{N}, \mathrm{N}, \mathrm{O}$ donor and formed 1:2 complex $\left(\mathrm{ML}_{2}\right)$ by coordinating with $\mathrm{Mn}$ (II) through quinoxaline ring nitrogen, azomethine nitrogen and phenolic oxygen. The complex was found to be active against gram positive bacterial strains Bacillus subtillis, Staphyloccocus aureus and also exhibited strong binding affinity towards CT- DNA with an intrinsic binding constant, $4.416 \times 10^{6}\left(\mathrm{M}^{-1}\right)$.

\section{References}

[1]. Manju Sebastian , V. Arun , P.P. Robinson, Annu Anna Varghese , Rani Abraham ,E. Suresh , K.K. Mohammed Yusuff Polyhedron 29 (2010) 3014-3020.

[2]. P.V.Anantha lakshmi, D.Sandhya Rani, V.Jayatyagaraju Asian J. Chem.7,2 (1995),296-306

[3]. P.V. Anantha Lakshmi1, P. Saritha Reddy, V. Jayatyaga Raju Bull. Chem. Soc. Ethiop. 22, 3, (2008), $385-390$.

[4]. D Sandhya Rani, PV Anantha Lakshmi, V Jayatyaga Raju Research Journal of Pharmaceutical, Biological and Chemical Sciences 5, 2 (2014). 1304.

[5]. Muneerah M. A .Mogren, Abdel-Nasser, M. A. Alaghaz Int. J. Electrochem. Sci., 8,(2013) 8669-8685.

[6]. Ane F.da S. Santos, Leandro L.de Oliveira, José R. a S. Maia IOSR Journal of Applied Chemistry, 9, 12, (2016), 54-62 .

[7]. B.S. Creaven, B. Duff, D.A. Egan, K. Kavanagh, G. Rosair, V.R. Thangella, M. Walsh, Inorg.Chim.Acta 363, (2010), 4048-4058.

[8]. A.N. Kursunlu, E. Guler, F. Sevgi, B. Ozkalp, J. Mol. Struct. 1048, (2013), 476-481.

[9]. Firasath Unnisa, B. Sireesha D. A. Padmavathi IOSR Journal of Applied Chemistry, 9, 7 (2016), 06-22.

[10]. Averi Guha, Jaydeep Adhikary,Tapan Kumar Mondal,Debasis Das Ind. J. Chem 50A(2011)1463-1468.

[11]. K. R. Justin Thomas, Marappan Velusamy, Jiann T. Lin, Chang-Hao Chuen, and Yu-Tai Tao Chem. Mater. 17, 7, (2005) 1861.

[12]. Serrif. Adewuyi ,Gangli ,Shu Zhang, Wenquing Wang, Peng Hao, Wen-hua Sun, Ning tang, Jianjun Yi J. Organomet. Chem. 692, (2007) 3532-3541.

[13]. C.Justin Dhanaraj, Jijo Johnson J. Photochem. Photobiol., B. 151(2015)100-109.

[14]. P.Krishnamoorthy, P.Sathyadevi,Alan H.Cowley, Rachel R.Butorac, N.Dharmaraj Eur. J. Med. Chem. 46 (2011) $3376-3387$.

[15]. Mugdha R. Suryawanshi, Vithal M. Kulkarni, Kakasaheb R. Mahadik, Sharad H. Bhosale Archives of Applied Science Research 3,1, (2011): 380-391.

[16]. Pabla nobia, Marisol Vieites, Maria H.Torre, Antonio J. Costa -Filho, Hugo Cerecetto, Mercedes Gonzalez, Maria Laura Lavaggi, Yusuke Adochi, Hiromu Sakurai, Dinorah Gambino J. Inorg. Biochem. 100 (2006) 281-287.

[17]. Andres Jaso, Belen Zarranz, Ignacio Aldana, Antonio Monge Eur. J. Med. Chem. 38 (2003) $791-800$.

[18]. Montague Alexandra Phillips J.Chem.Soc. (1928) 2393-2399 DOI: 10.1039/JR9280002393.

[19]. G.W.H.Cheeseman and M. Rafiq, J.Chem.Soc (C), 453, (1971), 452-454 DOI: 10.1039/J39710000452.

[20]. HuiluWu; Tao Sun; Ke Li; Bin Liu; Fan Kou; Fei Jia; Jingkun Yuan; Ying Bai. Bioinorg. Chem. Appl., 2012, Article ID 609796.

[21]. RK Sahu; F Khan; Kush Nayak. Chemistry and Materials Research. 7, (2015), 40-47.

[22]. FarukhArjmand,Shazia Parveen, Mohd Afjal, Mohd Shahid, J. Photochem. Photobiol., B 114(2012) pg15-26.

[23]. Justin Dhanaraj chellian,jijo johnson, Spectrochim. Acta, Part A.127 (2014) 396-40.

[24]. Mendu Padmaja, J. Pragathi, B. Anupama, C. Gyana Kumari E-Journal of Chemistry 9,4, (2012), $2145-2154$.

[25]. Philip J.Cose, George Psomas, Christos A.Bobs Bioorg. Med. Chem.17 (2009) 6054-6062. 